『英文誌』J. Nucl. Sci. Technol., Vol. 35, No. 10, pp.685７27（October 1998）和文抄録

\begin{abstract}
$\diamond$ 研 究論 文
${ }^{181} \mathrm{Ta}$ に関する $140 \mathrm{MeV}$ まで光核反応データの評価(Evaluation of Photonuclear Reaction Data on Ta-181 up to 140 $\mathrm{MeV})$ : 李 榮旭, 深堀智生, 張 鐘和, pp.685 691.

${ }^{181} \mathrm{Ta}$ の光核反応断面皘を $\pi$ 中間子生成しきい值の $140 \mathrm{MeV}$ 以 下のエネルギー領域で評価した。SaclayおよびLivermoreで湘

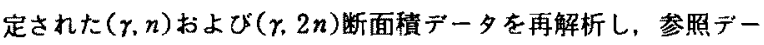
夕として再構成した。 $40 \mathrm{MeV}$ 以下の光吸収断面皘は，電気的双 極子巨大共鳴モデルを用いて評価した。前平衡モテルによって補 正された統計模型計算結果は，すへてての光中性子生成断面積参照

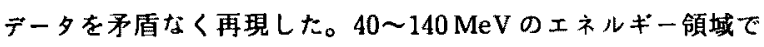
は, 疑似重陽子モデルを用いて光吸収断面積を評価し, 実験值と 比较した。中性子, 陽子, 二・三重陽子、 ${ }^{3} \mathrm{He}$ 原子核， $\alpha$ 粒子に関す る粒子崩塤過程はALICE-Fコードを用いて評洒された。
\end{abstract}

置換クロマトグラフィLi同位体分離におけるHETPに対する 流量率の影㹂 (Effect of Flow Rate on Height Equivalent to a Theoretical Plate for Li Isotope Separation with Displacement Chromatography)：荒术秀樹, 榎田洋一, 山本一良, pp. $692 \sim 696$.

ポーラス型イオン交換臌脂を用い Li溶液の流量率を変化させ て, 一連の置換クロマトグラフィLi同位体分晟実験を行った。 楁液の流量率はそれぞれの同位体分離実験で $0.1 \sim 20 \mathrm{~cm}^{3} / \mathrm{min}$ と した。これは界面移動速度の 0.0012 加ら $0.26 \mathrm{~cm} / \mathrm{s}$ に相当する。 クロマトグラフィ装置の分離性能を表わす分離係数とHETPの 評価のために，カラムから流出する際，およびサンプルフラク ション内での $\mathrm{Li}$ 同位体の混合を考虑して，溶出液中の ${ }^{6} \mathrm{Li} €$ ル分 率プロファイルとHETPについての関保式を導出した。この関 係を用いて分離係数わよびHETPを同時に決定した。分離係数 は前端分析法で得られた值之実験䛊差の籍囲内で一致した。実験 加得られたHETPは実験の筙囲内では流量率ととあに増加し た。粒内搪散抵抗は溶液の栘流による分散とともに，HETPに対 して大きな影斐を与えることが示唆された。

ドデカンの放射線分解と物性值变化：参照用HAカラム1回通 過線量を基にして(Radiolysis of $N$-dodecane and Its Physical Property Change; Based on the dose in one pass through a reference HA columns）：池田秀松, 鈴木篤之, pp. 697 704.

希釈唷およひ洗浄剤として使われるド゙ンンの放射線分解生成 物とその物性值変化について，ピューレックス HA塔での線量を 想定した ${ }^{60} \mathrm{Co}$ 線源による照射実験を行った。まず，HAカラムを 1 回通過する時に有機相が受ける線量を，参照用HAカラムを用 いて計算した。ついで，この1回通過線量を基にして，商用ドデ カンの放射線分解実験を行った。 $\gamma$ 線による分解生成物の化学種 は線量につれて增加するが、ドデカンの G 值は吸収線量が 1.01 Wh/lを超えると減少した。実験結果と既往の研究から，開放系 でのア線による主要な生成化学種と化学反応について考察した。 また，物性値の変化は小さかったが，無視できる量ではなかっ た。なお，環状型とノスルブレートの組合せで線量が低減され た。

日本原子力学会誌、Vol. 40, No. 10 (1998)
HIP 接合により慗作した核融合第一壁搆造体の低サイクル疲 労寿命 (Low Cycle Fatigue Lifetime of HIP Bonded Bi-metallic First Wall Structures of Fusion Reactors)：秦野歳久，佐藤 憕, 黒田敏公, 高津英幸, 橋本俊行, 喜多村和憲, 古谷一幸, 榎枝 幹男, pp. 705 711.

国際熱核融合実䮖炉(ITER)における遮蔽ブランケットの第一 壁は，了ルミナ分散強化銅の熱シンク層とステンレス鋼の冷却管 を应散接合の一種である高温静水圧加圧(HIP) 接合により一体化 する複合構造を有する。このような異材接合複合構造体の疲労寿 命を評価するため，第一壁部分モデルをHIPにより製作し，低 サイクル疲学試験(機械荷重)を行った。試鉙条件は応力比 -1.0 . 昰子䡉囲0.2、0.3，0.5，0.7，1.0\%の5 条件で実施した。公称歪 みに対する武験片内部の歪み分布を評価するため弾塑性解析も実 施した。すべての試験片で初期き裂はステンレスの冷却管内部に 発生し、これは解析において得られた最大歪みの発生位置と一致 した。武験お゙び解析結果の比較より第一壁 HIP 構造体の疲労 寿命はステンレス母材の疲労データよりも長寿命側であることが 明らかとなった。また，第一壁構造体の HIP 接合部の疲労寿命 る材料試験で得られた疲労データよりも長寿命例であった。この ことは，材料試験で定められる設計疲労曲線に基づいた第一壁疲 労寿命設計が十分な安全率を有することを示唆しているものと考 えられる。

\section{$\diamond$ 技術報告৩}

イント新型重水妒の総合試験装置における目然循環举動を模挺 するための出力ー体皘に関するスケーリング則の適用性 (Adequacy of Power-to-volume Scaling Philosophy to Simulate Natural Circulation in Integral Test Facilities): Arum Kumar Nayak, P.K. Vijayan, Dilip Saha, V. Venkat Raj, 有富正憲, pp. $712 \sim 722$.

自然循環挙動を模擬でき，インド新型重水炉(AHWR)の総合 試験装置(ITF-AHWR)の設計に適用できる出力一体積に関する スケーリング則を確立するために，理論的，実験的研究を実施し た。それらの䊅果から，出力ー体積に関するスケーリング則に基 つくく縮小模擬試験装置における流路径の縮小は、プロトタイプの 装置の自然话愣举動の模擬に影辢を与える可能性があることが明 らかになった。これは，縮小規模装置の摩擦抵抗の模擬ができな いことに起因している。そこで，縮小模擬装置の流路径はできる だけ原形炬に近つけることを提案した。この提案を，出力一体積 に関するスケーリング則に基づき，200MW出力のインド型加圧 重水原型炬 (PHWR) 用の模擬武験装置(FISBE-1)の自然謟環挙 動と比较することにより検証した。数学モデルと解析コードを用 いた検討から，FISBE-1は原型炉の定常状態と過渡自然循環举 動の一般的な傾向をよく模擬することがわかった。最後に，提案 するスケーリング則をITF-AHWRの設計に適用した。

$\mathrm{H}_{2} \mathrm{O}-\mathrm{HTO}$ 水蒸留の分離性能に及ぼす漂れ壁塔内径の影暨 (Effect of Inner Radius of Wetted-wall Column on Separative Performance of $\mathrm{H}_{2} \mathrm{O}-\mathrm{HTO}$ Water Distillation）：杉山貫彦，榎田 洋一,山本一良, pp. 723 727.

蒸気相および液相濃度分布を同時に求める計算コードを開発し $\tau, \mathrm{H}_{2} \mathrm{O}-\mathrm{HTO}$ 同位体分離用水蒸留の分離性能に及に゙す濡九壁塔 
『英文誌』J. Nucl. Sci. Technol., Vol. 35, No.10, pp. 728～736（October 1998）和文抄録

内半径の影暃を調へた。このコードによる結果を内半径 $R=3$ $\mathrm{mm}$ および $8 \mathrm{~mm}$ の需れ壁塔を用いた全還流運転条件の $\mathrm{H}_{2} \mathrm{O}-\mathrm{HTO}$ 水蒸留の実験結果と比較した。 $R=3 \mathrm{~mm}$ の場合の全 分離係数は $R=8 \mathrm{~mm}$ のそれよりも大きく、これは数值解析によ 万䂆测とよく一致した。蒸発速度定数 $k_{v_{v} A}$ の理論的最大值 1.57 $\times 10^{4} \mathrm{~cm} / \mathrm{s}$ の場合の全分離係数の計算結果は, 比較的 Reynolds 数の大きな領域で，全分離係数の実質的な上限を与えた。

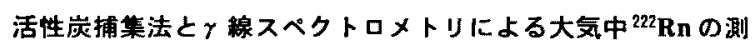
定(Airborne ${ }^{222} \mathrm{Rn}$ Measurement by Active Sampling with Charcoal Adsorption and Gamma-Ray Spectrometry) : 静間 清, 浜中俊一, 温 小㻴, 深見健司, 岩谷和夫, pp.728 732.

大気中のラドン浱度の簡便な測定法について叝告。大気中のラ トンを吸引法により活性炭に捕集した。ラトンと哣寿命子孫核種 が放射平衡に達することに基づき， ${ }^{214} \mathrm{~Pb} の$ 線測定からラドン
濃度を決定した。この測定法による大気中ラドン濃度の検出限界 は0.79 $\mathrm{Bqm}^{-3}$ と見積もられた。本吸引法で決められたラトンの 吸着係数を受動的 (passive) 測定法での報告值と比較する。この

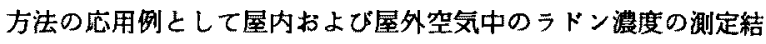
果を示す。

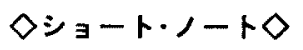

${ }^{13} \mathrm{C}$ の光核反応全断面栍における微勫櫣造の超高分解能測定 (Super High Resolution Measurement of Fine Structure in the Total Photonuclear Cross Section of ${ }^{13} \mathrm{C}$ ) : 原田秀郎, 古高 和祜, 重留義明, 大垣英明, 豊川弘之, pp. 733 735.

日本原子力学会誌(Vol.40, No.10)英文抄録, p.736.

\section{々日本における「同位体分離のあゆみ」々}

\section{日本原子力学会「同位体分離」特別専門委員会編}

\section{8年 3 月中白発行 (限定出版)}

B5 判, 400頁, 会員特価4,000円 (定価5,000円，消費税込)，送費450円

こ希望の方は学会事務局へ。（TEL 03-3508-1261；FAX 03-3581-6128；E-mail：atom@mtg.biglobe.ne.jp）

本書は, 戦後における「同位体分離のあゆみ」をまとめたものである。技術開発の軌跡やエピンード,開発の苦労話, 失敗談なよ゙，実体験に基づく記録や初公開の興味潹い内容が多く含まれています。本書が同位体分離の研究・開発・工 業化に関する意義のみならず，新しい課題の解決を目指す人にヒントを与える知恵袋としての役割を期待しています。

目次

（第 1 部）記念講演の記録

日本における同位体分離研究の歴史, 私のウラン濃縮遍歴

（第 2 部）技術開発の記録

第 1 章 ウラン浱㒕の研究と技術開発

第 2 章 重水素およびトリチゥムの濃縮

第 3 章 重窒素の分離および濃縮
第 4 章 重炭素の分噰および灙縮

第 5 章 重酸素の分離および管綰

第6 笪 ボロン、リチウムの分離

第 7 章 ガドリニウム,シリコンの分離

第 8 章 放射性希がスの分離

（第 3 部）「同位体分離」特別專門委員会の記録 